\title{
SHOOTING DIVERSITY IN LITHUANIAN YOUTH FEMALE BASKETBALL PLAYERS IN CENTRE POSITION DEPENDING ON THE RANK OF COMPETITION LEVEL
}

\author{
Šarūnè Valinskaitė, Aurimas Jasilionis, Antanas Skarbalius
} Lithuanian Academy of Physical Education, Kaunas, Lithuania

\begin{abstract}
Research background and hypothesis. Higher levels of competition rank have significant influence on the structure and shooting performance in youth basketball.

The aim of the study was to investigate the interaction of shooting and match results of Lithuanian female youth national team players dependent on the competition level.

Research methods. The basketball players $(\mathrm{n}=7)$ of the Lithuanian Basketball Centre were investigated. The performance indicators of those players were analyzed on the basis of the data collected during the Lithuanian Women "A" league and European Basketball Championship of 2011. We analyzed the statistics of six selected key indicators: 2- and 3- point field goal attempts, free-throws. The data were processed by SPSS 17.0 for Windows. Person's correlation coefficients were calculated to determine the relationships between the match results within all shooting types and different players.

Research results. The top efficacy of shooting was found in Lithuanian Championship (LC), the lowest - in European Championship (EC). The highest efficiency of free throws was found in the $\mathrm{II}^{\text {nd }}$ period $(62.53 \%)$, twopoints $(44.74 \%)$ and three-points $(19.45 \%)$ shooting efficacy in the $\mathrm{I}^{\text {st }}$ period in LC. Seven players of LBC in Lithuanian Championship earned the majority part of all points i. e. $74 \%$ in the $\mathrm{I}^{\mathrm{st}}$ period and $75 \%$ in the $\mathrm{II}^{\text {nd }}$ period. However, the contribution of 7 players of LBC in the international competition level of EC was less, $59 \%$ of total team points.

Discussion and conclusions. Though the players performed successfully and efficiently in both stages of LC and won all matches with a great difference in points, remarkable decrease in shooting efficacy and winning one match only (out of 9) in EC might be considered as not adequate level of mastership in the opponents' teams in LC or not adequate individual level of sport performance. Lithuanian basketball federation should rethink the system of targeted training of the Lithuanian youth team during the preparatory period in order to manage suitable local competition level for better advance in the performance at the international level.
\end{abstract}

Keywords: sport performance, sport games, sport contest model, shooting efficacy in basketball.

\section{INTRODUCTION}

$\mathrm{M}$ atch analysis is common in performance sport to guide training and competition. However, it is not as common at the youth level. Most studies about match analysis have studied the variables of technique and tactics in relation to final actions of a team's ball possession (Ortega et al, 2006).

The more complex the sport, the more attention should be given to what would be analyzed: the team or individual (athlete), and the aspects to be analyzed: individual actions or the most relevant key indicators of the team (Hughes, Franks, 2006).

Basketball match research has shown that winning teams outperform losing teams in shooting field - goals and securing defensive rebounds (Sampaio, Janeira, 2003; Sampaio et al., 2010).

The information that is available during a game is diverse and extensive. Continuous action 
and a dynamic environment make objective data collection difficult. Any quantitative analysis must be structured (Hughes, Franks, 2006).

The pattern of seasonal variation in game statistics is likely to depend on team quality because the best teams will have the best players in enhanced training environments, which will have an impact on game performance (Sampaio et al., 2010).

Permanent quantitative (Karipidis et al., 2001; Stonkus, 2002, 2003) and qualitative (Sampaio, Janeira, 2003) analysis enable to assess sport performance in basketball and predict future tendencies (Hughes, Franks, 2006; Reilly, 2007).

Some studies analyze the shot from a multifactorial focus, with samples from different competition levels. S. J. Ibánez et al. (2009) studied the American professional leag. ue (NBA), Ibánez et al. (2008) analyzed the professional Spanish league (ACB), and G. Tsitskaris et al. (2002) analyzed the Greek professional league.

The number of points scored is the key indicator characterizing basketball teams' offensive character and game performance. It certainly depends on objective factors: the opponents' playing style, number of capable team players, team tactics in competitions (Sampaio, Janeira, 2003).

Playing in high performance women's teams, the outcome of the match determines the accuracy of the shots, especially shots from near and middistance positions (these shots make the greatest number of all shots) (Klimantovicz, 1999; Stonkus, 2002, 2003; Jeličić et al., 2010).

Only a few studies have analyzed youth teams (Sampaio et al., 2004). In both cases of analysis, the majority of the authors analyzed the variables related to the final actions of ball possessions such as shots, efficacy percentage, assists, turnovers, steals, personal fouls received, points scored, or other variables like rebounds or even fast breaks (Sampaio et al., 2004). Most of these studies conclude that two-point shots by the team and the efficacy percentage of them are the key indicators of winning (Taxildaris et al., 2001; Fotinakis et al., 2002; Ibanez et al., 2003; De Rose, 2004).

Shooting efficacy and match results dependence on the shooting position according to age and mastership of players require more research (Sampaio et al., 2004).

The aim of the research was to investigate the interaction of shooting and match results of Lithuanian female youth national team players depending on the competition level.

Subject of research: interaction of shooting and sports results.

\section{RESEARCH METHODS}

Participants. In order to improve the pattern of playing style, the best 14 players from Lithuania were selected in the Lithuanian Basketball Centre (LBC). The team took part in different Lithuanian basketball leagues (Table 1), all players took part in the Lithuanian Women Basketball League "A" (LWBAL) as a team, but only 7 players from the LBC took part in the European Championship'2011 (U-18).

Measurement. At the beginning of the season in September, 2010, players were measured (height $-1.79 \pm 0.01 \mathrm{~m}$, body mass $-66.14 \pm 6.09$ $\mathrm{kg}$ ). Players were divided into guards, forwards and centers (Table 1).

Data collection. Data sets were gathered from publicly available sources at the Lithuanian Women's Basketball "A" league website (http://www.lmkal. lt), student's (http://www.mkl.lt), and LWBL (http:// www.lmkl.lt) of the 2010-2011 season. Statistics of matches $(n=19)$ were registered according to the regulations of the Federation International Basketball Association (FIBA). Competitive period started on Octobe17, 2010, and lasted until May 15, 2011, its final stage $(n=9)$ started on August 4
Table 1. The number of Lithuanian basketball players in different basketball leagues
Note. LSBL - Lithuanian Students Basketball League.

\begin{tabular}{|c|c|c|c|c|}
\hline Leagues & LSBL * & LWBAL & LWBL & Total \\
\hline $\begin{array}{c}\text { Players } \\
\text { Centers }\end{array}$ & $\mathrm{n}=6$ & $\mathrm{n}=18$ & $\mathrm{n}=29$ & $\mathrm{n}=53$ \\
1. & $\mathrm{n}=15$ & & $\mathrm{n}=15$ \\
\hline 2. & $\mathrm{n}=18$ & $\mathrm{n}=17$ & & $\mathrm{n}=35$ \\
\hline Guard & $\mathrm{n}=19$ & $\mathrm{n}=24$ & $\mathrm{n}=58$ \\
\hline Forwards & $\mathrm{n}=18$ & $\mathrm{n}=19$ & & $\mathrm{n}=37$ \\
1. & $\mathrm{n}=18$ & $\mathrm{n}=18$ & & $\mathrm{n}=36$ \\
2. & $\mathrm{n}=18$ & $\mathrm{n}=18$ & $\mathrm{n}=21$ & $\mathrm{n}=57$ \\
\hline 3. & & & & \\
\hline
\end{tabular}


and lasted until August 14, 2011 (http://u18women. fibaeurope.com/en/). The age of players altered during the season (Table 2).

Table 2. Participant's age in different playing periods

\begin{tabular}{|c|c|c|c|}
\hline & 2010 September & 2011 March & 2011 August \\
\hline Age & $16.93 \pm 0.45$ & $17.60 \pm 0.67$ & $17.91 \pm 0.42$ \\
\hline
\end{tabular}

We analyzed statistics of six selected key indicators: 2 - and 3 - point field-goal attempts (both successful and unsuccessful), free-throws (both successful and unsuccessful).

Statistical analysis. To ensure a normal sample distribution, the Kolmogorov-Smirnov test was applied. Kruskal-Wallis test was applied to analyzed nonparametric data. The data are presented as means $(\bar{x})$ and standard deviations (s). Statistical significance was set at $\mathrm{p}<0.05$. The data were processed by SPSS 17.0 for Windows. Person's correlation coefficients were calculated to determine the relationships between match result within all shooting types and different players. Correlation coefficients (r) above 0.5 were considered as representing large correlations, 0.3 to 0.5 - moderate, 0.1 to 0.3 - small, and $<0.1-$ insubstantial/trivial according to Cohen (1988).

\section{RESEARCH RESULTS}

Shooting efficacy. The highest efficacy of shooting was found in Lithuanian Championship (LC), the lowest in European Championship (EC).
The highest efficiency of free-throw shooting was found in the $\mathrm{II}^{\text {nd }}$ period $(62.53 \%)$, two-point shooting efficacy - in the $\mathrm{I}^{\text {st }}$ period $(44.74 \%)$, threepoint efficacy $-\mathrm{I}^{\text {st }}$ period (19.45\%) in LC (Figure 1).

We found different levels of correlation when analyses was made for 12 players and for the main 7 players who scored $58 \%$ of total points in EC. Correlation of all 12 players ranged from trivial to large at all levels of competition. The significant interaction was found between the scored points and successful two-point field goal and two-point field goals efficacy in the $\mathrm{I}^{\text {st }}$ period of LC and in EC. However, significant interaction between the scored points and successful free throw and free throws efficacy was found for 7 players in EC only. Significant interaction of playing efficacy by guard player was found between scored points ant free throws in the II ${ }^{\text {nd }}$ period of LC. Significant interaction was found between scored points and two-point field goals efficacy in LC and between scored points and made free throws in EC by forwards, as by centers between scored points and made two-point field goals and free throw efficacy in EC, between scored points and made two-point field goals and efficacy in I period.

Shooting efficacy from various playing positions. A significant difference $(\mathrm{p}<0.05)$ between free-throws and three-point shooting efficacy was found in the $\mathrm{I}^{\text {st }}$ period, between freethrows in the $\mathrm{II}^{\text {nd }}$ period in $\mathrm{LC}$, and between twopoints and three-points in EC compared to players from all different positions (Figure 2).

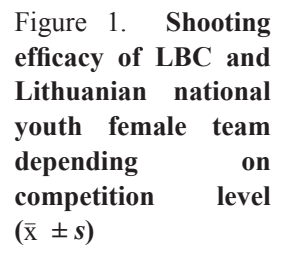

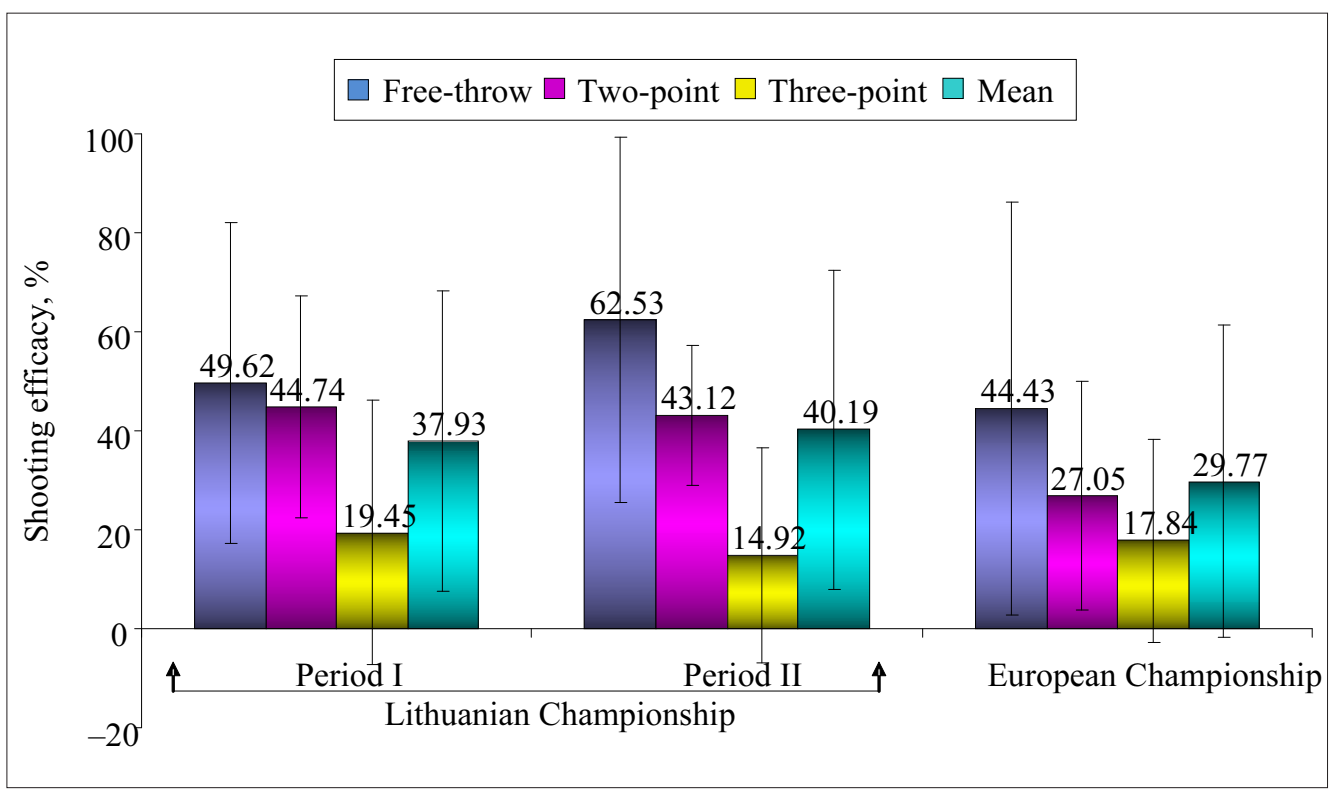


Structure of points scored per match. Two-point field goals were the major in points composition independently of competition level $\left(\mathrm{I}^{\text {st }}\right.$ period $-60.91 \%, \mathrm{II}^{\text {nd }}$ period $-60.78 \%, \mathrm{EC}-$ $54.19 \%$ ). Free-throws composed the least part in point structure (Figure 3). The more three-point field goals $(24.45 \%)$ were performed in EC than in LC both periods.
Contribution in the number of points by $L B C$ players. Seven players of LBC in Lithuanian Championship ( $\mathrm{I}^{\text {st }}$ and $\mathrm{II}^{\text {nd }}$ period) made the major part of all points i. e. $74 \%$ in the $\mathrm{Ist}^{\text {st }}$ period and $75 \%$ in the $\mathrm{II}^{\text {nd }}$ period. However, contribution of LBC players in international competition level $\mathrm{EC}$ was not significant compared to the national one: 7 players mentioned before scored $59 \%$ of total team points.

Table 3. LBC players' correlations of different evaluated points and playing positions

\begin{tabular}{|c|c|c|c|c|c|c|c|}
\hline $\begin{array}{l}\text { Number } \\
\text { of players }\end{array}$ & $\begin{array}{c}\text { Rank of } \\
\text { competition } \\
\text { level }\end{array}$ & $\begin{array}{l}\text { Scored points and } \\
\text { successful two- } \\
\text { point field goals }\end{array}$ & $\begin{array}{c}\text { Scored points } \\
\text { and two-point } \\
\text { field goal efficacy }\end{array}$ & $\begin{array}{c}\text { Scored points } \\
\text { and successful } \\
\text { three-point field } \\
\text { goals }\end{array}$ & $\begin{array}{l}\text { Scored points } \\
\text { and three- } \\
\text { point field } \\
\text { goal efficacy }\end{array}$ & $\begin{array}{c}\text { Scored } \\
\text { points and } \\
\text { successful } \\
\text { free throws }\end{array}$ & $\begin{array}{l}\text { Scored points } \\
\text { and free } \\
\text { throw efficacy }\end{array}$ \\
\hline \multirow{3}{*}{12} & $\mathrm{EC}$ & $\mathrm{r}=0.53^{*}$ & $\mathrm{r}=0.64^{*}$ & $\mathrm{r}=0.71 * * *$ & $\mathrm{r}=0.31$ & $\mathrm{r}=0.53$ & $r=0.56$ \\
\hline & Period I of LC & $\mathrm{r}=0.83^{*}$ & $\mathrm{r}=0.76^{* *}$ & $\mathrm{r}=0.18$ & $\mathrm{r}=0.31$ & $\mathrm{r}=0.34$ & $\mathrm{r}=0.16$ \\
\hline & Period II of LC & $\mathrm{r}=0.85^{*}$ & $r=0.64$ & $r=0.67$ & $\mathrm{r}=0.13$ & $\mathrm{r}=0.06$ & $\mathrm{r}=0.35$ \\
\hline \multirow{3}{*}{7} & $\mathrm{Ec}$ & $\mathrm{r}=0.38$ & $\mathrm{r}=0.42$ & $\mathrm{r}=0.32$ & $\mathrm{r}=0.36$ & $\mathrm{r}=0.79 * *$ & $\mathrm{r}=0.69^{*}$ \\
\hline & Period I of LC & $\mathrm{r}=0.69 * * *$ & $\mathrm{r}=0.80 * *$ & $\mathrm{r}=0.11$ & $\mathrm{r}=0.07$ & $\mathrm{r}=0.15$ & $\mathrm{r}=0.06$ \\
\hline & Period II of LC & $\mathrm{r}=0.74^{*}$ & $\mathrm{r}=0.93 * *$ & $\mathrm{r}=0.43$ & $\mathrm{r}=0.17$ & $\mathrm{r}=0.25$ & $\mathrm{r}=0.45$ \\
\hline \multirow{3}{*}{ Guard } & $\mathrm{Ec}$ & $\mathrm{r}=0.17$ & $\mathrm{r}=0.08$ & $\mathrm{r}=0.06$ & $\mathrm{r}=0.06$ & $\mathrm{r}=0.1$ & $\mathrm{r}=0.15$ \\
\hline & Period I of LC & $\mathrm{r}=0.15$ & $\mathrm{r}=0.23$ & $\mathrm{r}=0.23$ & $\mathrm{r}=0.16$ & $\mathrm{r}=0.35$ & $\mathrm{r}=0.03$ \\
\hline & Period II of LC & $r=0.68$ & $\mathrm{r}=0.42$ & $\mathrm{r}=0.23$ & $\mathrm{r}=0.34$ & $r=0.67$ & $\mathrm{r}=0.79 * *$ \\
\hline \multirow{3}{*}{ Forwards } & $\mathrm{Ec}$ & $\mathrm{r}=0.05$ & $\mathrm{r}=0.02$ & $\mathrm{r}=0.18$ & $\mathrm{r}=0.02$ & $\mathrm{r}=0.73^{*}$ & $\mathrm{r}=0.53$ \\
\hline & Period I of LC & $r=0.43$ & $\mathrm{r}=0.58^{*}$ & $\mathrm{r}=0.23$ & $\mathrm{r}=0.07$ & $\mathrm{r}=0.03$ & $\mathrm{r}=0.21$ \\
\hline & Period II of LC & $\mathrm{r}=0.78^{*}$ & $\mathrm{r}=0.89 * * *$ & $\mathrm{r}=0.31$ & $\mathrm{r}=0.07$ & $\mathrm{r}=0.31$ & $\mathrm{r}=0.02$ \\
\hline \multirow{3}{*}{ Centers } & Ec & $\mathrm{r}=0.67^{*}$ & $\mathrm{r}=0.41$ & $\mathrm{r}=0.34$ & $\mathrm{r}=0.34$ & $\mathrm{r}=0.41$ & $\mathrm{r}=0.74 * * *$ \\
\hline & Period I of LC & $\mathrm{r}=0.56^{*}$ & $\mathrm{r}=0.65^{* * *}$ & Not shooting & Not shooting & $r=0.06$ & $\mathrm{r}=0.4$ \\
\hline & Period II of LC & $\mathrm{r}=0.03$ & $\mathrm{r}=0.04$ & Not shooting & Not shooting & $r=0.45$ & $\mathrm{r}=0.33$ \\
\hline
\end{tabular}

Note. $*-\mathrm{p}<0.05, * *-\mathrm{p}<0.005, * * *-\mathrm{p}<0.01$. Level of correlation: $<0.1-$ insubstantial/trivial; $0.1-0.3-$ small; $0.3-0.5-$ moderate; $>0.5-$ large

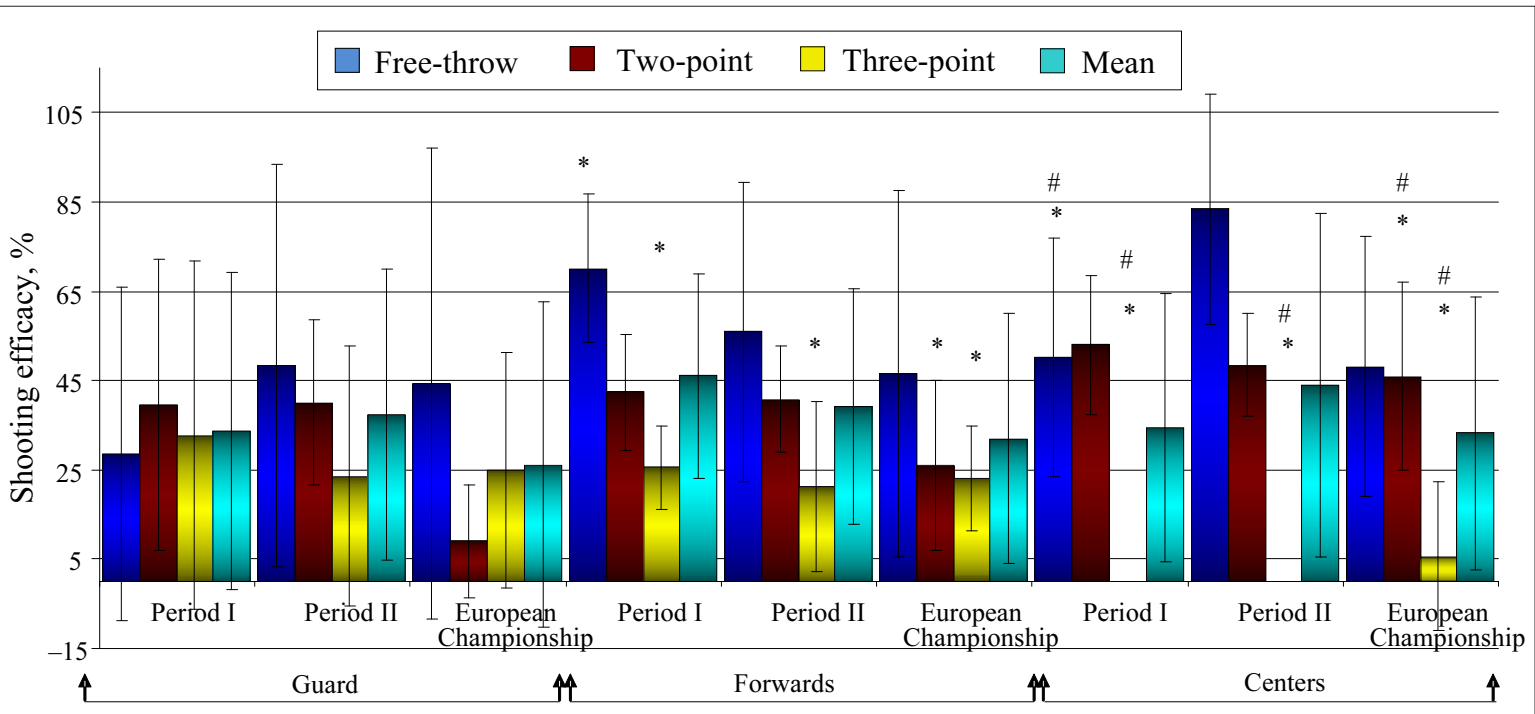

Figure 2. Efficiency of shooting from different positions in LC'2011 and EC'2011 by LBC and Lithuanian national youth female team

Note. $*-p<0.05$ between guard and others (forwards and centers), $\#-p<0.05$ between forwards and centers 
Figure 3. Structure of points scored per match in different competition ranks
Figure 4. Contribution of LBC players at Lithuanian championship (period I and period II) and at European Championship compared to total team points
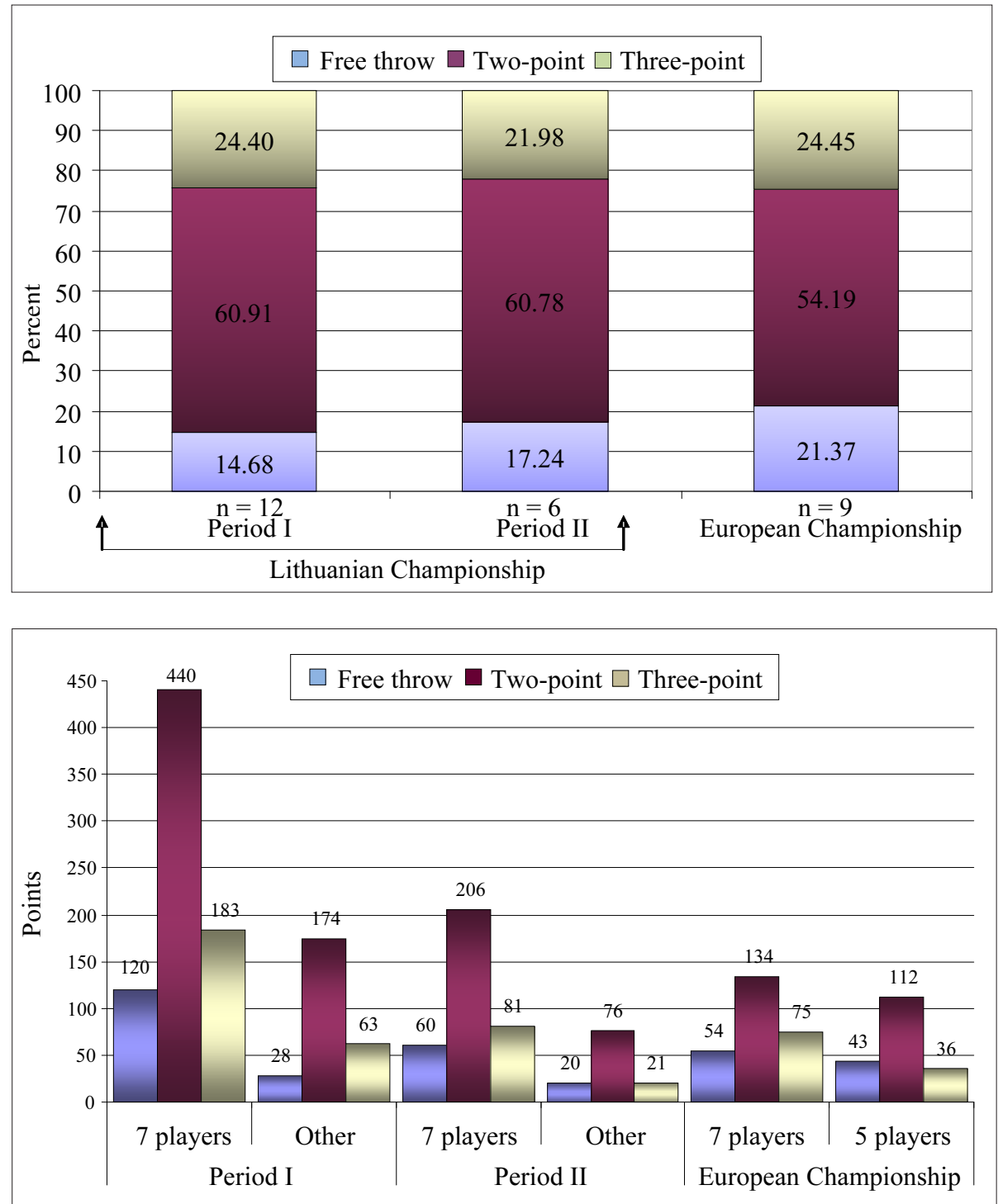

\section{DISCUSSION}

Points per match. Researchers suggest (Trninić et al., 2002; Sampaio, Janeira, 2003; Sampaio et al., 2010) that points scored per match are the key indicators in basketball as per se in order to win. We found high correlation between scored points and winning points $0.868(\mathrm{p}<0.01)$ in EC.

Elite women's winning teams scored $(68.2 \pm 7.9) 10$ points more compared to losing teams $(57.7 \pm 8.3)$ at the European Women Basketball Championship'2009 (Kreivyte, Čižauskas, 2010). Male youth teams of the same age (17-18 years) as we observed scored nearly the same points $(71.7 \pm 2.3)$ in the European Championship'2008, but Lithuanian Youth Male national team scored less $69.6 \pm 4.6$ (Matulaitis, Stonkus, 2009).

Maintaining high performance during the season is a complex but key target for all team ball sports (Sampaio et al., 2010), especially depending on the level of competition. The fact that points scored per match decreased in the end of season more than by 30 points might be considered as the factor of mastership the Lithuanian youth team at the EC, or limitation of players' fitness (Trninić et al., 2002). Basketball as a complex sport should be given to what will be analyzed (Hughes, Franks, 2006). The opponents' playing style, number of capable team players, team tactics in competitions might have essential influence on the outcome of match (Sampaio, Janeira, 2003).

We found high correlation $(\mathrm{r}=0.54 ; \mathrm{p}<0.05)$ between scored points and missed points, between scored points and the difference in scored and missed points $(r=0.91 ; p<0.05)$ in the Lithuanian championship (period I and II), but small correlation was observed $(r=0.127 ; p>0.05)$ in the EC. The same tendency of relationship between scored and missed points to winning points was found in EC. 
Those findings allow asserting that successful team actions in defense make positive prerequisite for counterattacks and scoring more points (Šeparović, Nuhanović, 2008). Concerning the Lithuanian youth team case, we can make presumption by different levels of competing teams in Lithuanian championship and higher level in EC.

Structure of points related to shooting position. Basketball match analysis research has shown that winning teams outperform losing teams in shooting field-goals (Sampaio, Janeira, 2003; Trninić et al., 2002). M. Jeličić and co-authors (2010) analyzed European Basketball Championship in 2000 and found that the number of two-point field goals was the primary situational parameter for the overall successfulness in the game, whose efficiency was averaging between 50 and $60 \%$, and comprised 55 to $60 \%$ of the total number of points at a basketball match. The interaction between scored points and performance in 2-point field-goals suggests limited differences between important players from all teams, but marked differences between less important players from all teams (Sampaio et al., 2006). In our research the number of two-point field goals per match was less by $5 \%$, efficacy of two-point field goals was less by $17 \%$ in EC than in the $\mathrm{I}^{\text {st }}$ and $\mathrm{II}^{\text {nd }}$ periods of LC. Reducing number of two-point field goals per match and two-point field goals efficacy might be considered as a fact that Lithuanian national girl youth team in EC were forced to miss a lot of shoots from two-point field because of opponent teams' defense applied. On the other hand, we can assume that models of different playing styles were not applied in the preparation period.

The most interesting finding was that freethrows composed the quarter of points per match in EC, but they were less significant in LC. The greatest changes of free-throws can allow asserting active defense system by opponents in EC. The number of points scored in the key indicator characterizing basketball teams' offensive character, game performance, and it depends on objective factors: the opponents' playing style, number of capable team players, team tactics in competitions (Sampaio, Janeira, 2003). The opportunity to stop a team from scoring with defense pressure can be a key determinant of success of a team (Trninić et al., 2000). The pattern of seasonal variation in game statistics is likely to depend on team quality because the best teams will have the best players in enhanced training environments, which will have an impact on game performance (Sampaio et al., 2010).
The highest level performances are typically very consistent across a variety of sports and the level of competition. Athletes are able to maintain consistency in their performance (Hopkins, Hewson, 2001). The fact that players performed successfully and efficiently in both stages of LC and won all matches with great difference in points, remarkable decrease in of shooting efficacy and winning one match only (out of 9) in EC, might be considered as inadequate level of mastership by opponent teams in LC or inadequate individual level of sport performance. Since the highest level of performers has the highest fitness, there may be a link between fitness and consistency of performance late in the season and the level of competition (Drinkwater et al., 2007). Lithuanian Basketball Federation should rethink the system of targeted training of the Lithuanian youth team in order to manage suitable competition level for better advance performance in the future. Those findings by mentioned researchers allow asserting unpredictable influence on the performance of the Lithuanian Youth Girls' team in EC because of the higher results but lower levels of competition in both periods of $L C$.

Effectiveness of scored points by players of different positions. The most important and primary role of the guards is to organize the game flow in the phase of offence. S. Trninić et al. (1999) suggest that guards have executed the greatest number of attempted throws from the three-point field goal area most often; they have the fewest shooting attempts from the two-point goal area. The higher level of competition gives the higher level of defense and the lower level of shooting efficacy (Sampaio et al., 2010). Three-point field goal efficacy was less by $7 \%$ than in the $\mathrm{I}^{\text {st }}$ period, by $2 \%$ more than in the $\mathrm{II}^{\text {nd }}$ period, but free throw efficacy was better by $16 \%$ in EC compared to the $\mathrm{I}^{\text {st }}$ period. The fact that two-point field goals efficacy by guard player was less by $30 \%$ in EC compared to the $\mathrm{I}^{\mathrm{st}}$ and $\mathrm{II}^{\text {nd }}$ periods of LC might be considered as not enough level of opponents in LC.

Forwards are in almost all variables interposed between guards and centers. Forwards are generally considered to be the creators of play. The additional features of their performance are: many attempted throws from both the half-distance and distance (although having fewer three-point goals than the guards); a significant contribution to the flow of performance by a great number of passes (Trninić et al., 1999). The performance of Lithuanian youth team forwards was less in EC (two-point field goals 
efficacy was less by $14 \%$, three-point field goals efficacy was less by $15 \%$, and free throw efficacy was less by $24 \%$ ) and that might be considered as low level of mastership.

Centers of Lithuanian team attempted twopoint field goals contrary to the fewest three-point goal throws, and two-point field goals efficacy was less by $8 \%$ in EC. Centers in EC showed the highest level of mastership in shooting efficacy compared to forwards and guard. Centers are above average in shooting from the two-point goal area with good efficiency, they make a great number of free throws (Trninić et al., 1999). However, two-point goal efficacy of our centers was lower than average. In the phase of offence play they are mostly under their basket, so they execute many inside throws. When playing one-on-one and/or one-on-two with their back to the basket they forced the opponents' personal foul, but free-throw efficacy of centers was less $35 \%$ in EC compared to LC. Due to the fact of not enough international experience, centers missed possibilities to score the points.

\section{CONCLUSIONS AND PERSPECTIVES}

The results make clear that shooting characteristics are different with regard to competition level of the players. Coaches should know the specific characteristics of their competition to adequately prepare their players. Likewise, the knowledge of these differences should help orientate the formation process of the inexperienced players in order to facilitate their transition to peak performance. Those findings allow asserting unpredictable influence for the performance of the Lithuanian Youth Girl Team in EC because of the higher results but lower level of competition in both period of LC. Lithuanian Basketball Federation should rethink the system of targeted training in the Lithuanian youth team in order to manage suitable competition level during preparation period. Permanent sport performance monitoring should be applied in order to assess the right targeted training process in preparation period.

\section{REFERENCES}

Cohen, J. (1988). Statistical Power Analysis for the Behavioral Sciences. London: Routledge.

Drinkwater, E., Hopkins, W. G., McKenna, M. J., Hunt, P. H., Pyne, D. B. (2007). Modeling age and secular differences in fitness between basketball players. Journal of Sports Science, 25 (8), 869-878.

Fotinakis, P., Karipidis, A., Taxildaris, K. (2002). Factors characterizing the transition game in European basketball. Journal of Human Movement Studies, 42, 305-316.

Hayes, D. (1987). Body segment contribution to free throws shooting in Basketball. Biomechanics in Sports. Proceedings of the Fifth International Symposium of Biomechanics in Sports (pp. 205-211). Athens: Hellenic Sports Research Institute.

Hay, J. G. (1994). The Biomechanics of Sports Techniques. USA: Practice-Hall. P. 211-234.

Hopkins, W. (2002). A new view of statistics [26 04 2008]. Internet link: http://www.sportsci.org/ resource/stats/effectmag. html

Hopkins, W., Hewson, D. (2001). Variability of competitive performance of distance runners. Medicine and Science in Sports and Exercise, 33, 1588-1592.

Hughes, M. D., Franks, I. M. (2006). Notational Analysis of Sport: Systems for Better Coaching and Performance in Sport. Second edition. London and New York: Routledge.

Ibanez, S. J., Feu, S., Garcia, J., Parejo, I., Canadas, M. (2009). Shot differences between professional (ABC) and amateur (EBA) basketball. Revista de Psichologia del Deporte, 3, 313-317.
Ibanez, S. J., Sampaio, J., Saenz-Lopez, P., Gimenez, F. J. (2003). Game statistics discriminating the final outcome of junior world basketball championship matches (Portugal, 1999). Journal of Human Movement Studies, 45, 1-19.

Jeličić, M., Trninić, M., Jeleska, I. (2010). Latent structure of situational efficiency of elite junior basketball players. Sport Science, 3 (1), 65-70.

Karipidis, A., Fotinakis, P., Taxildaris, K., Fatouros, J. (2001). Factors characterizing a successful performance in basketball. Journal of Human Movement Studies, 41, 385-397.

Klimontowicz, W. (1999). Koszykowka. Warszawa: Centralny oszrodek sportu.

Ortega, E., Cardenas, D., Sainz de Baranda, P., Palao, J. M. (2006). Differences between winning and losing teams in youth basketball games (14-16 years old). International Journal of Applied Sports Sciences, 2, 1-11.

Reilly, T. (2007). The Science of Training - Soccer. London: Routledge

De Rose, D. (2004). Statistical analysis of basketball performance indicators according to home/away games and winning and losing teams. Journal of Human Movement Studies, 47, 327-336.

Sampaio, J., Drinkwater, E. J., Leite, N. M. (2010). Effects of season period, team quality, and playing time of basketball players' game related statistics. European Journal of Sport Science, 10 (2), 141-149.

Sampaio, J., Ibanez, S., Feu, S. (2004). Discriminatory power of basketball game-related statistics by level of competition and gender. Perceptual and Motor Skills, 99, 1231-1238. 
Sampaio, J., Janeira, M., Ibanez, S., Lorenzo, A. (2006). Discriminant analysis of game-rated statistics between basketball guards, forwards and centers in three professional leagues. European Journal of Sport Science, 6, 173-178.

Sampaio, J., Janeira, M. (2003). Statistical analyses of basketball team performance: Understanding team's wins and losses according to a different index of ball possessions. International Journal of Performance Analysis in Sport, 3 (1), 40-49.

Stonkus, S. (2002). Krepšinio testai. Kaunas: LKKA.

Stonkus, S. (2003). Krepšinis. Istorija. Teorija. Didaktika. Kaunas: LKKA.

Šeparović, V., Nuhanović, A. (2008). Nonstandard indicators of the offensive effectiveness in basketball and successfulness of basketball teams. Sports Science, $1,7-11$.

Taxildaris, K., Papadimitrou, K., Alexopoulos, P. et al. (2001). Factors characterizing the offensive game of the playmaker position in basketball. Journal of Human Movement Studies, 40, 405-421.

Trninić, S., Dizdar D., Dežman, B. (2000). Empirical verification of the weighted system of criteria for the elite basketball players quality evaluation. Collegium Antropologicum, 24, 443-465.

Trninić, S., Dizdar, D., Fressl, Ž. J. (1999). Analysis of differences between guards, forwards and centers based on some anthropometric characteristics and indicators of playing performance in basketball. Kinesiology, 31 (1), 29-36.

Trninić, S., Dizdar, D., Luksic, E. (2002). Differences between winning and defeated top quality basketball teams in final tournaments of European club championship. Collegium Antropologicum, 26, 521-531.

Tsitskaris, G., Theoharopoulos, A., Galanis, D., Nikopoulou, M. (2002). Types of shots used at the Greek National Basketball Championship according to the division and position of players. Journal of Human Movement Studies, 42, 43-52.

\title{
LIETUVOS JAUNIŲ MERGINŲ KREPŠINIO CENTRO ŽAIDE்JŲ METIMŲ İ KREPŠİ YPATUMŲ PRIKLAUSOMUMAS NUO VARŽYBŲ RANGO
}

\author{
Šarūnè Valinskaitė, Aurimas Jasilionis, Antanas Skarbalius \\ Lietuvos kūno kultūros akademija, Kaunas, Lietuva
}

\section{SANTRAUKA}

Tyrimo pagrindimas ir hipotezė. Aukštesnio rango varžybos reikšmingai veikia merginu jaunių krepšininkiu metimų struktūrą ir veiksmingumą.

Tikslas - ištirti Lietuvos merginų jaunių rinktinès žaidèjų metimų ir rungtynių rezultatų priklausomumą nuo varžybų rango.

Metodai. Buvo tirtos Lietuvos krepšinio centro $(\mathrm{LKC})$ krepšininkės $(\mathrm{n}=7)$. Žaidẻjų varžybinės veiklos rodikliai buvo analizuojami iš surinktu duomenų per Lietuvos moterų krepšinio „A“ lygos pirmo ir antro etapo ir Europos čempionato'2011 rungtynes. Analizuoti 6 rodikliai: dvitaškiai, tritaškiai ir baudos metimai. Duomenys apdorojami SPSS 17.0 programa. Pirsono koreliacijos koeficientas buvo skaičiuojamas nustatant ryšius tap rungtynių rezultato ir metimų i krepši bei žaidèju amplua.

Rezultatai. Didžiausias metimų veiksmingumas buvo Lietuvos čempionato (LČ) metu, mažiausias - Europos (EČ). Didžiausias baudos metimų veiksmingumas - II LČ etapo metu (62,53\%), dvitaškių metimų veiksmingumas I LČ etapo metu (44,74\%), tolimų metimu - I LČ etapo metu (19,45\%). Septynios LKC žaidèjos LČ pelnè didžiausią dali komandos taškų: 74\% I ir 75\% II etape. Tačiau tarptautinio lygio rungtynėse LKC septynių žaidèjų indèlis sudare $59 \%$ visų komandos pelnytų taškų.

Aptarimas ir išvados: Žaidèjų metimų veiksmingumas LČ leido LKC komandai laimèti visas rungtynes dideliu taškų skirtumu, tačiau dèl ryškiai mažesnio metimų veiksmingumo EČ Lietuvos rinktinei pavyko laimèti tik vienas rungtynes iš devynerių. Nesèkmingo Lietuvos rinktinès žaidimo EČ priežastimi galèjo būti arba nepakankamas varžovių lygmuo LČ, arba nepakankamas individualus žaidejų meistriškumas. Lietuvos krepšinio federacija turètu permąstyti Lietuvos jaunujų krepšininkių komandos tikslinio rengimo sistemą pasirengimo laikotarpiu sudarydama tinkamą varžybų lygmeni, kad būtų garantuotas ir komandos, ir žaidèjų individualaus meistriškumo tobulèjimas.

Raktažodžiai: parengtumas, sportiniai žaidimai, varžybinės veiklos modeliai, metimų i krepšș veiksmingumas.

Gauta 2012 m. kovo 23 d.

Received on March 23, 2012

Priimta 2012 m. birželio $8 \mathrm{~d}$.

Accepted on June 8, 2012
Corresponding author Antanas Skarbalius Lithuanian Academy of Physical Education Sporto str. 6, LT-44221 Kaunas

Lithuania

Tel +37068216807

E-mail a.skarbalius@lkka.lt 